\title{
'Reasonable pricing' may be dropped from NIH deals
}

\section{Former KGB agent clears Bohr of passing secrets}

Washington. The US biomedical industry received an indication last week that the National Institutes of Health (NIH) may reverse a policy known as 'reasonable pricing', under which the NIH can set a 'reasonable price' for products developed out of collaborative research projects.

The clause has been included by the NIH since 1989 in all Cooperative Research and Development Agreements (CRADAs) introduced by Congress in 1986 to encourage technology transfer from federal laboratories - made with research groups in its intramural programme. The move followed controversy over the price of the antiretroviral drug $\mathrm{AZT}$.

But the clause is deeply unpopular with the biomedical industry, which sees it as a potential vehicle for imposing price controls on biomedical products, and argues that it is therefore a major barrier to collaborative projects with scientists working in the institutes' \$1.1-billion in-house programme.

The reasonable pricing clause was the hottest topic under debate at a meeting convened last week by NIH to discuss CRADAs. The panel included not only industrialists, academics and patient advocate groups, but also NIH officials.

Many industrialists feel that other provisions within the agreements already give the government adequate protection.

The industry is also worried that after spending money on research, trials and commercialization, the NIH, under congressional pressure, might exercise the reasonable pricing clause in its CRADA in a way that the industry considers unreasonable.

Chris Doherty, Washington director of a coalition of research hospitals, industry and patient advocate groups, says that, as a result, industry is not taking full advantage of the NIH's intramural programme. "This is a foolish situation," he says.
The biomedical industry's complaints about reasonable pricing have been fanned by uncertainty over the price controls that may accompany President Bill Clinton's proposed health-care reform.

Alison Taunton-Rigby, president of Mitotix, a biotechnology company in Cambridge, Massachusetts, says that venture capital companies have a checklist for companies they are considering investing in. "One of the things they ask is whether you have any CRADAs that include a reasonable pricing clause," she says. "It is a black mark if you do."

NIH officials acknowledge the problem. Publicly, they are not prepared to say that the reasonable pricing clause is likely to be dropped in all cases. But many feel that it should be.

Lisa Raines, vice-president for government affairs at the biotechnology company Genzyme, suggested an alternative clause insisting that a drug company should provide reasonable access to patients who cannot afford a particular therapy. Neither Mitotix or Genzyme are prepared to enter CRADAs with the NIH under the current terms.

Much of the discussion at last week's meeting centred on finding arguments for the panel's final report supporting a proposal that reasonable pricing should not be mandatory in all cases. Any change would take time to make its way through the federal bureaucracy. It could also run into opposition from Congress, some of whose members are keen that the principle embedded in the clause be maintained.

But industrialists at the meeting expressed optimism. "If we can eliminate this clause, we are prepared to sit through the months of negotiations that are a part of doing business with the government," said Taunton-Rigby. Helen Gavaghan

\section{Silk worms fall prey to night stalker}

New Delhi. A small lizard is being blamed for sabotaging an Indian research project to breed superior silkworms through genetic engineering. The centimetre-long lizard had been feasting nightly on silkworm eggs that had been genetically manipulated and left in a cage to hatch.

Elimination of the nocturnal invader has finally saved the research project. "But we nearly lost six months' work," says K. P. Gopinath, head of the microbiology department at the Indian Institute of Science in Bangalore.

Under a project funded by the Department of Biotechnology, Gopinath has been working to improve the Indian mulberry silkworm (Bombyx mori) by introducing beneficial genes from a chinese strain. The project was going well until staff noticed that the eggs and the larvae were disappearing from their cage "One morning we would count 30 eggs, the next day it will drop to 15 , and the following day the cage will be empty," said Gopinath. After three months staff decided to keep the cage under 24-hour surveillance, and spotted the lizard entering the cage through a small opening after the lights had been extinguished.

K. S. Jayaraman

Moscow. Recent claims by the former Soviet agent Pavel Sudoplatov that Niels Bohr was involved in passing US atomic bomb secrets to Soviet agents have been contradicted by the evidence of a former KGB scientist sent to obtain information from the eminent Danish physicist in 1946.

The accusations were included in Sudoplatov's book Special Tasks, published earlier this year, which has been widely criticized for its accusation that many leading Western physicists, in particular Robert Oppenheimer, helped the Soviet bomb programme by providing critical scientific information (see Nature 368, 799; 1994).

But the diary of Yakov Terletsky, a physicist and a former employee of the KGB, the Soviet intelligence service, published in a

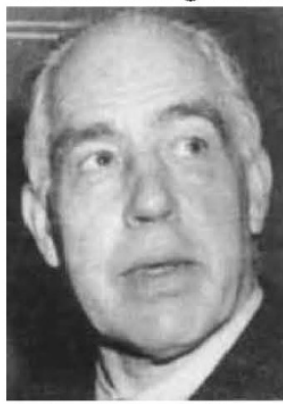

Bohr: 'gave nothing away'. recent issue of the journal The Issues of Science and Technology History, reveals a different picture. It recounts how in 1946 Lavrenti Beria, chief of security for the Russian bomb project, ordered the KGB to contact Bohr, who at the time had a reputation for supporting open international relations in the area of atomic warfare.

Terletsky later told researchers that he asked questions prepared for him by Soviet scientists such as Igor Kurchatov, Yuly Khariton and Isaac Kikoin. "Bohr calmly answered all questions, but his answers were general," says Terletsky in the diaries.

Kurchatov subsequently reported to Beria that the 'Bohr interrogation' was of little value. He said that Bohr had not provided any new material, and that most of the information was already publicly available.

Terletsky said the operation had been largely a formality, designed to rebut charges that the KGB was not doing enough to help those working on the bomb.

According to Terletsky, his meeting with Bohr was intended primarily to indicate to Kurchatov that he could not put the blame for the delay on a lack of intelligence data by providing him with an opportunity to address questions to Bohr himself.

Vladimir Vizin, a specialist in the history of the atomic project, suggests that Kurchatov, Khariton, Artsimovich and Kikoin may have been reluctant to endanger Bohr through suggestions that he was a Soviet spy, and therefore compiled questions whose answers would contain little information. 